\title{
Law in other contexts Legalise it! The rising place of law in French sociology
}

\author{
Liora Israël** \\ École des Hautes Études en Sciences Sociales (Paris), Centre Maurice Halbwachs
}

\begin{abstract}
By highlighting a large number of recent studies mainly based on empirical methods, the aim of this paper is to emphasise and illustrate the rising influence of legal sociology in France today, and the interesting results produced. More generally, it is noteworthy to emphasise the growing importance of law and legal domains as a topic of great interest in French social sciences in general. It remains an open question whether this trend is linked to the 'judicialisation' of French politics and society and its influence over the academic field, or, alternatively, to the growing capacity of social scientists to resist the monopolistic claim of French academic lawyers on the analysis of legal subjects and to develop their own. Nevertheless, those trends converge towards a better knowledge of French legality, relevant from a national perspective, as well as to assess its contribution to socio-legal knowledge in general.
\end{abstract}

As André-Jean Arnaud and Pierre Noreau wrote in I998, in the last attempt to present French socio-legal studies to an English-speaking audience, 'to suggest that French legal sociology is a field in which a dominant theoretical tendency is identifiable is misleading' (Arnaud and Noreau, I998). Almost fifteen years later, the verdict is globally the same, even if the frontiers of the 'field' are not so evident. Is it (still) possible today to identify a French way of doing things in the world of socio-legal research? Inevitably, it is a question that needs to be addressed in such a paper. If one focuses on the country studied, we may as well include foreign researchers working on France (Stone Sweet, I992; Bowen, 2007). If we refer to the country of origin of the researcher, he or she - albeit French - may also study other countries (Vigour, 2004; Vauchez, 2004; Thireau and Hua, 200I), work in collaboration with a colleague, notably from the American law and society tradition, to refer to two famous 'duos' (Garth and Dezalay, Karpik and Halliday), or even work in France as a foreign national while studying a third country (Dupret, 2006a). The French language is also used by colleagues in various regions, notably for the socio-legal research in Québec (Canada), in Belgium or in Switzerland, and is not to be considered as related only to French research. What I will consider as 'French' sociology of law in this paper would be within this research field, as defined by belonging to a French research institution and participating in national debates. Following GarciaVillegas (Garcia-Villegas, 2009), I assume that French institutions, legal as well as academic, are to be taken into account in understanding the scientific findings of French socio-legal scholars.

It is noteworthy that the field has evolved rather quickly since Arnaud and Noreau's (I998) paper, notably in the direction of a stronger institutionalisation within sociology and political science, in contrast with a growing lack of interest in law faculties. But it is also in terms of content that the sociology of law has developed in directions that were not always anticipated. If the eight paradigms they identified may still be relevant for categorising some of the main questions

* I am grateful to Lisa Hilbink for her help on an earlier version of this paper, and to David Nelken and the anonymous reviewers for their comments. 
addressed by socio-legal scholars, they failed to capture the ways in which the rise of empirical studies modified both the structuration of the community, its relation to other fields of research, and the picture of law and society produced. By highlighting a large number of recent studies mainly based on empirical methods, I would like to emphasise and illustrate the rising influence of legal sociology in France today, and the interesting results produced. I would also like to suggest another neglected issue, namely the rising importance of law and legal domains as a topic of great interest in French social sciences in general. It remains an open question whether this trend is linked to the 'judicialisation' of politics and society and its influence over the academic field, or, alternatively, to the growing capacity of social scientists to resist the monopolistic claim of lawyers on the analysis of legal subjects ... and to develop their own. Nevertheless, those trends converge towards a better knowledge of French legality, relevant from a national perspective as well as from assessing its contribution to socio-legal knowledge in general.

\section{Institutional legacies and hidden heritages}

André-Jean Arnaud and Pierre-Noreau depicted well how legal sociology in France was framed and institutionalised in the second half of the twentieth century. The influential jurist Jean Carbonnier played a major role in the legitimation of applied legal sociology in the I96os, including as an adviser of the Minister of Justice, Jean Foyer (Vauchez, 2005; Commaille, 2007). Several sociologists were hired by the Ministry of Justice in the I970s, under the supervision of former magistrate Philippe Robert, to produce the 'legislative sociology' promoted by Carbonnier. But the interest in new interdisciplinary research on law can also be linked to the rise of activist and/or critical approaches to law, originating either from legal professionals (notably the 'Syndicat de la Magistrature', a left-wing union developing among magistrates since the late I960s, including Philippe Robert), or from critical thinkers, philosophers - Poulantzas and Foucault mainly - and academic lawyers representing the French equivalent of the critical legal studies movement, 'Critique du droit' (Dupré du Boulois and Kaluszynski, 20II). Whether oriented towards governmental action, or highly critical of the use of law in the reproduction of cultural and social hegemony, those approaches developed more strongly from the mid I980s under the umbrella of a few institutions created by the two main actors in the structuration of the field: law professor André-Jean Arnaud and sociologist Jacques Commaille. In 1986, they founded the main French socio-legal journal, Droit et Société, and they were associated with the field's major achievement, directed by Arnaud, the Dictionnaire Encyclopédique de Théorie et de Sociologie du droit [Encyclopedia of Jurisprudence and Sociology of Law] (Arnaud, I993). They also contributed to the constitution of networks at national and international level (notably the Réseau Européen Droit et Société REDS ${ }^{\mathrm{I}}$ ), and institutions such as the International Institute for the Sociology of Law created in Oñati, Spain, whose first director was Arnaud.

This broad framing of the structuration of the field around the mid I980s and early I990s was already apparent in Arnaud and Noreau's (1998) paper, even if they may have underestimated, out of modesty, the intellectual influence of Jacques Commaille and André-Jean Arnaud themselves. At the same time, the authors may have paid too much attention to the intellectual legacy of Jean Carbonnier for contemporary French legal sociology. Indeed, although one must acknowledge that Carbonnier was crucial as a promoter of the term 'sociology of law' (Carbonnier, 1969), as well as a mentor to young socio-legal scholars, it is clear today that his legacy is not large. In an interview with Arnaud published in I995 (Andrini and Arnaud, I995), Carbonnier himself recognised that he did not really have heirs, and today it is obvious that the legacy of his legislative sociology is almost undetectable. The 'Laboratoire de sociologie juridique' that he created in I968 still exists,

〈http://www.reds.msh-paris.fr/anglais/accueil.htm〉. 
but it is mainly composed of legal academics in the classical sense of the term, and the group's research questions are above all legally oriented, despite interesting outcomes in more theoretical domains, as attested by an important volume published on the sociology of law of Max Weber (Heurtin and Molfessis, 2006). Carbonnier's main influence may reside in the continuing reflection on the relation between legal change and family patterns, well represented today in the work of Irène Théry (Théry, I993; 2010).

What can be considered as the major trend of current French socio-legal research may be the move from a conception of law in the books to the attention paid to law in action. This formula, explicitly borrowed from legal realism, should not be reduced to the growing influence of international scholarship, and more precisely of the 'Law and Society' tradition progressively introduced to a French audience (Dezalay, Sarat and Silbey I989; Vauchez, 200I). Indeed, it is also a dynamic that one can understand as part of a broader evolution of sociology in France towards subjects rather than theoretical frameworks, an evolution that can be traced, and may be explained, in various dimensions: the standardisation of subdisciplines in the sociological curricula of French universities (sociology of education, urban sociology, political sociology, etc.); the organisation of thematic sections in the French Sociological Association, refounded in 2002; the growing influence of international organisations (the International Sociological Association, European Sociological Association, etc.), themselves organised thematically. This trend materialised in various ways in the domain of legal sociology: the publication of handbooks such as Evelyne Serverin's Sociologie du droit (2000) or Beaudouin Dupret's Droit et Sciences Sociales (2006b), with others being forthcoming; the creation of a network of the French Sociological Association on the 'Sociology of Law and Justice' in 2002; as well as the creation of academic positions labelled 'sociology of law' in sociology departments, including one at the École Normale Supérieure in 2009 and the opening of one for the CNRS² recruitment campaign in 20I2. And, of course, this recognition was associated with, and even constitutive of, a growing body of research, focused either on legal and juridical institutions or on the lives of law in society.

This rising institutionalisation of the sociology of law in the sociological discipline is the clearest recognition of the intellectual rejuvenation of legal sociology in general, as attested by various publications. But it is also important to try to restore part of the heritage from the recent past that was not captured by Arnaud and Noreau (such a review inevitably being incomplete). They notably omitted a very significant book, still underestimated today, Nicolas Herpin's L'application de la loi. Deux poids, deux mesures (Herpin, 1977). This silence is all the more surprising given that the book met success at the time of its publication, with the general public as well as among legal professionals. In a striking but unnoticed parallel with the paradigmatic study of Marc Galanter, 'Why the "Haves" Come Out Ahead', published three years earlier (Galanter, I974), Herpin's cautious analysis, mainly based on the ethnography of criminal courts in Paris, demonstrated the unfairness of justice, notably by stressing the fact that verdicts were more severe for members of the working classes. His explanations, drawing on a combination of ethnography, institutional analysis, quantitative analysis of the verdicts and the sociology of the judicial professions, provided a convincing account of the unfairness of justice as an institution. The fact that early decisions combined with the biographical careers of the accused strongly determined the trajectory of a case was at the core of the sociological explanation. This book is then to be considered as a landmark for its contribution to the demonstration of the repression that the judicial institution exerted in criminal law over the most deprived section of the population (including immigrants), in accordance with the theoretical criticism developed notably in Marxist philosophy concerning law (Poulantzas, I965).

2 French National Centre for Scientific Research. 
In terms of theoretical framing, the references mobilised by Herpin are interesting: he referred very broadly to Max Weber, as well as to the interactionist tradition, with Erving Goffman, both of whom were later at the core of the growing interest towards an empirical study of law in the I980s and I 990 (Lascoumes and Serverin, I988). Herpin also quoted another neglected study of the courts, by Raymond Boudon and André Davidovitch, on non-prosecution (Boudon and Davidovitch, I964). This quantitative analysis developed in the early I96os referred to the theoretical work of Gabriel Tarde to explain non-prosecution as the result of the anticipated consequences of a decision by the judge. Herpin himself combined the use of ethnography with a strong commitment to quantitative analysis: he knew both approaches very well from his time at Columbia University in the late I96os, 3 which led to his first book, a seminal work on American sociologists in the twentieth century (Herpin, I973). In contrast to the obligatory reference to the 'founding fathers' of French sociology of law who are often cited - from Durkheim, Marx and Weber to Lévy-Bruhl or Carbonnier - neither Boudon nor Goffman, as cited by Herpin, were known for their contribution to the sociology 'of law' in particular. Moreover, Herpin did not stay in the field of legal sociology, with some exceptions (Herpin, I98I), and is renowned today as a sociologist of consumption (Herpin, 200I). Beside his striking contribution to the study of the courts in action, one original aspect of Herpin's analysis - and maybe the reason that Arnaud and Noreau overlooked him - was that the framework he used to analyse justice was based on general sociology instead of the sociology of law. His work can thus be considered as a precursor of the movement to reconceptualise legality in the general framework of the social sciences, without giving priority to a restricted set of authors previously associated with the sociology of law. He thus opened the way to new types of enquiry, such as the ethnographic analysis of the courts, notably for petty crime (Christin, 2008).

It is possible to defend the idea that the current renewal of French legal sociology is to be understood in relation to a de-specification of the field, that is, its opening beyond the lines of an applied sociology in the service of juridical institutions. Jacques Commaille for years strongly advocated the return of legal sociology to the field of general sociology (Commaille, I99I). It may have happened, not as a move from a subfield to the field, but through the integration of various socio-legal scholars, often trained in other domains and/or whose main fields of interest were not always initially law or justice. It was also nurtured by new institutions, notably the 'Mission de recherche Droit et Justice' [Office for the Research on Law and Justice], created in I994 to support research on legal and judicial issues on behalf of the Ministry of Justice, in which Georges Garioud from the CNRS has been playing a central role.

From there, what can be seen in the field of socio-legal research may be described as a dissemination of the interest in legality as a social question through various channels. The rejuvenation of legal sociology may thus have required a partial neglect of the history of the subdiscipline, explaining today's lack of interest towards Carbonnier or Gurvitch (Soubiran-Paillet, 2000) and their rather fuzzy and somehow methodologically blurry conception of legal sociology. In contrast, it is through the deep empirical analysis of various subjects, at the crossroads of various sociological traditions and methods, that the sociology of law re-emerged. This evolution is of importance because it permitted the development of numerous studies all over French society, along various lines of enquiry.

\section{Law is all over ... society: the force of law in various terrains}

My hypothesis is that new trends in the sociology of law were able to gain in cohesiveness through the new institutional framework inherited from the previous period (the journal Droit et Société,

Interview with Nicolas Herpin, December 20 I I. 
REDS) and developed in the early 2000s, in relation to the growing influence of international research, and notably of the Law and Society Association. The more fruitful research has certainly developed through hybridisation, at the crossroads of other subfields of sociology. In those various domains, one main idea was challenged and discussed: the fact that law should be considered - or not - only as a 'force', in the ways that Pierre Bourdieu described it in the mid I980s in a famous paper called 'The Force of Law' (Bourdieu, I986). Bourdieu insisted on the social logics of the legal field, defining the legal field as 'the site for a competition for monopoly of the right to determine the law'. Albeit incredibly fruitful, Bourdieu's analysis may have underestimated the capacity of social agents to mobilise law (Roussel, 2004). Of course, most sociologists admit today that law, far from being neutral, is an agent of social reproduction. But sociologist of law try to focus precisely on the conditions under which the system functions, and notably on the tension between the moral definition of justice and the institutional life of law (Cottereau, 2002). Bourdieu's heirs themselves opened the ways to the integration of law in the analysis of the social world, for example Rémy Lenoir, who published, from a rather Durkheimian perspective, a sociohistorical analysis of family laws and morals (Lenoir, 2003), or Louis Pinto, who developed a more comprehensive analysis of law in daily life in his remarkable but rather unnoticed article on consumer law (Pinto, I989). Pinto focused on the various forms through which consumers expressed their dissatisfaction, already referring to the work of Austin Sarat or Susan Silbey to identify a common sense of law expressed by consumers in their interactions with various institutions. At a time when consumer rights were largely unsettled in France, he very convincingly depicted how citizens, in relation with consumer organisations, constructed arrangements to settle a certain number of litigious cases along various lines, including - but not exclusively - judicial arenas.

Pinto himself, despite this paper, is not known as a sociologist of law, because he later specialised in the sociology of intellectuals (Pinto, 2007); nonetheless, his article, in conjunction with Lascoume and Serverin's article on the use of Weber, can be considered groundbreaking towards the development within French sociology of new ways of tracing law in daily life. In this new approach, researchers distance themselves from the earlier analysis oriented towards law in courts, such as the (always interesting) research projects led by the CESDIP on criminal law, often based on statistics, ${ }^{5}$ or the type of 'gap studies' that Carbonnier had favoured in his attempts to modernise French legislation. In contrast to these older traditions of research, it is the daily lives of law in various settings that are at the core of several recent innovative studies. In this context, the issues of employment, labour and industrial relations are one of the more fruitful areas of development. This trend is not surprising in a French society strongly marked by a high rate of unemployment and a sense of 'precariousness', of 'social insecurity' in relation to work (Castel, 2003). The 'pull of the policy audience' (Sarat and Silbey, I988) is certainly under those circumstances a major explanation of the rising importance of the sociological interest towards labour laws and employment policies.

The 'Critique du droit' movement had already paved the way for this interest in labour laws, notably with the influential work of Antoine Jeammaud (Collin, Dhoquois, Goutierre and

4 This example shows that Arnaud and Noreau may have underestimated those cross-national references when they wrote that 'With few exceptions, French legal sociologists are not inclined to refer to either American or British sociology'. It is interesting to note that, despite their important work, neither Lenoir nor Pinto are cited in this earlier article.

5 The Centre for Sociological Research on Law and Criminal Justice Institutions (CESDIP) is a major venue for the study of criminal justice and deviance in France. The centre, initially directed by Philippe Robert, is a division of the French Ministry of Justice in charge of the analysis of the public response to crime and deviance, as well as an affiliate of the Centre National de la Recherche Scientifique (CNRS) and the Université de Versailles-Saint-Quentin (UVSQ). 
Jeammaud, I980). In sociology, Claude Didry was one of the first to engage in a reflection on the uses of law at work. In a paper with Luc Tessier on 'the cause of employment' (Didry and Tessier, I996), they selected three situations where employees were threatened by a collective dismissal procedure, and tried to understand their diverse patterns of action. They found legal mobilisation and its effects to be highly contextual. The main resources identified were: strong unionisation, the availability of economic expertise or the willingness of employees to fight. But the main condition for legal mobilisation was the possibility to redefine locally - in relation with new public procedures - an economic future for the firm. It is also mainly through monographs that Jérôme Pélisse engaged in an analysis of the implementation of the reduction of the working week under the Aubry laws in France at the end of the I990s. Notably, under the influence of the legal consciousness studies framework (Pélisse, 2005), he examined the processes by which employees made sense of the law, focusing on the vocabulary they used to describe the redefinition of their working conditions under the new legal framework (Pélisse, 2003). Those studies refined the social dimensions of legal implementation, by focusing on the micro-level to decipher 'rights at work' (McCann, I994). It was all the more important that they distanced themselves from a bottom-up approach, considering that the overseeing role of the state in France (Bourdieu, 20I2), by comparison with common-law countries, was to be confounded with a quasi-mechanistic implementation of laws. In contrast, the role of intermediaries, either jurists or members of unions, was to be considered central for the working conditions in the firm. This body of work also intersected with a growing field of research focusing on legal institutions as workplaces. Organisational studies of legal institutions, as developed initially at the Centre for the Sociology of Organisations in Sciences Po (Ackermann and Bastard, I990; Bastard and Mouhanna, 2007), provided a new picture of the judiciary, notably in the context of an increasing managerialisation of justice.

The focus on local and even linguistic dimensions can be understood as a shift in interest, from law in the workplace to law at work. The work of law in its mundane practice has been particularly targeted by some researchers, focusing on the compliance to new quality standards in the context of the company (Cochoy, Garel and de Tersac, I998), and the development of written accountability at the administrative level (Torny, 20II). Jean-Marc Weller analysed how civil servants allocate subsidies to farmers (Weller, 2007). He studied legal work as a practical activity, where the qualification of facts appears to be the main issue at stake, as Isabelle Sayn had already showed concerning family allowances services (Sayn, 2005). However, Weller, instead of considering a series of cases, focused on one single issue: the disappearance of two steers belonging to one farmer. This micro-history is treated just like the Italian micro-historia dealt with stories - often based on judicial archives (Ginzburg, I980): the thick description of a single case, apparently trivial, being at the core of an in-depth understanding of a complex social environment. Referring to Yan Thomas and Olivier Cayla, both professors of jurisprudence, Weller insisted on the fact that law can be considered as work in its ability to prepare a case to be treated by a juridical authority. Even if the process of adjustment is afterwards covered by the official designation chosen, the work of law, according to him, must be considered as a product of law even at the very local level, compliance being almost never a simple question. The famous injunction by Ronald Dworkin to 'take rights seriously' was turned into a methodological impetus, leading to a concentration on the local handlings of law.

From law at work to the work of law, the focus on situated action is certainly one of the main evolutions to be observed in the domain of the sociology of law in France (Ogien, I999, Fraenkel, Pontille, Collard and Deharo, 20I0). The turn towards legal activity (instead of considering law as something formal), based on ethnographical accounts, needs to be understood in reference to what is sometimes called 'French pragmatism', often associated, on the one hand, with the theoretical framework designed by Luc Boltanski and Laurent Thévenot in their masterpiece 'On justification' (Boltanski and Thévenot, 2006), and, on the other hand, to Bruno Latour and Michel 
Callon and their actor-network theory (Latour, 2005). It is interesting to note that these authors have recently paid more attention to law. Laurent Thevenot wrote an interesting piece on legal reasoning, in which he compared legal decisions with ordinary decisions, stressing the various conventional ways of justifying actions (Thévenot, 2006). Luc Boltanski, in conjunction with Elisabeth Claverie, also played a major role in bringing renewed attention to the political form known as the 'affair' (as in the 'Dreyfus Affair'), often associated with a major trial (Boltanski, Claverie, Offenstadt and Van Damme, 2007). They consider that 'affairs' constituted opportunities in the course of history to criticise and reassess the social order in relation to a moral breach provoked by a scandal. The study of affairs was then crucial in understanding the frailty and the legitimacy of the social order in various contexts. In a very different way, Bruno Latour also chose to devote one of his most recent books to a legal institution, the 'Conseil d'État' (Latour, 2002).

This is not the place for an in-depth analysis of Latour's book, which has recently been translated into English (Latour, 2010); however, it would be a mistake to neglect such an important contribution to the development of the French socio-legal field. First, one must signal how much influence the book has had on French socio-legal scholars, most notably in the accent on the material dimensions of legal work so remarkably described by Latour. The anthropologist benefited from an in-depth immersion in this prestigious and rather mysterious institution, leading him to focus on the material dimension of juridical work, and notably judicial files, enumerating the documents enclosed: various type of papers, paperclips, photographs, cardboard sleeves and other material artefacts being taken under consideration to identify the law as the vehicle creating a relation and a sense between those trivial objects. This elaboration has been widely recognised, ${ }^{6}$ yet it is important to mention that Bruno Latour pays almost no attention in his book to legal sociology, be it French or foreign. The research on the making of law at the level of the Conseil d'État was, in his perspective, a step forwards from his reflection on the nature of 'veridiction', that is, ways of establishing truth, in Western societies. Building on his prior, and very famous, work on the scientific laboratory (Latour and Woolgar, I979), he drew a comparison between the fabric of science and the fabric of law, offering a conception of legality as something 'pure', that should not be reduced to anything social. Since Latour is well known for his provocative standpoint, his refusal to ascribe social logics in the making of the law may have been neglected in the otherwise enthusiastic reception of his work in French sociology of law, which was mainly focused on the methodological aspects of the research. Another limitation of his book should be considered, in the title as in the whole book: the assumption that what could be observed at the level of the Conseil d'État could be extended unconditionally to depict law in France (as expressed by the title, The Making of Law). Notably, despite the fact that France is a civil-law country, Latour chose to scrutinise the making of law in a court, and did not pay attention to what is the major source of law in France: Parliament.

Beyond the book itself, Latour's approach may be associated with a third type of sociological research on legal matters in France. Above, I distinguished broadly between a body of scholarship taking law as its subject (the core of legal sociology as depicted by Arnaud and Noreau) and other works that were not always initiated directly in the domain but which represented the encounter of the legal object from other traditions and extended the boundaries of the field. Latour - as well as Boltanski and Thévenot - can be assigned to a third group, that of sociologists dealing with legal objects or institutions without paying any attention to a rather well-identified - at the time of their writing - body of scholarship in legal sociology. Despite their lack of inclusion in the field

6 For example, when the network 'Sociology of law and justice' of the French sociological association launched a call for papers asking 'Quelles théories pour la sociologie du droit et de la justice' ['What theories for the sociology of law and justice?'] in 2006, more than half of the proposals referred to Bruno Latour's book, published only four years previously. 
of socio-legal studies, their contribution should not be underestimated. On the contrary, their influence has been decisive in the last few years. Their lack of willingness to engage with other authors can be explained by their prominent positions and their own research agendas. It is nevertheless striking to observe that a few years later, when another major French sociologist, Dominique Schnapper, decided to write a book on the 'Conseil Constitutionnel', the French constitutional court, she also paid almost no attention to the existing body of literature on legal institutions in the social sciences. While some might point to these examples either to lament the lack of recognition of legal sociology or to condemn the fact that prominent sociologists do not pay attention to more modest and specialised actors in their field, it is also clear that these works are above all a sign of growing interest in law and legal subjects in the social sciences in France. This interest can also be linked to a variety of research, either in French contemporary history (Thénault, 200I; Mouralis, 2008; Lemercier, 2008), or anthropology (Assier-Andrieu, I996; Claverie, 2009), and even philosophy (Delpla, 2012), reassessing the importance of law and justice in politics and society, and the willingness to treat them from the perspective of social sciences, without leaving it to law alone - as an academic discipline - to deal with. As the role of law in society is more generally emphasised, the monopoly that jurists trained exclusively in law have had on legal subjects, legal philosophy, legal history or jurisprudence in France is all the more challenged. Jurists themselves may be turned into the subjects of enquiries to analyse the social and political legitimisation of their expertise (Vanneuville, 2009). This trend is at the same time supporting and exceeding the boundaries of socio-legal research in France as a relatively autonomous subfield. And the main result of the process is certainly the growing recognition of the place of law and legal institutions in the understanding of French society, beyond the range of theoretical orientations.

\section{The politics of law in France: from the juridicisation of politics and society to the common place of law in politics}

One of the major subjects of French socio-legal research in the last twenty years has been the study of the relations between law and politics (Commaille and Duran, 2009). Two main traditions were initially confronted, one issued from Bourdieu's thought, the second developed by Lucien Karpik. Following in the steps of Pierre Bourdieu's analysis of law (Ocqueteau andt Soubiran-Paillet, I996), Alain Bancaud developed a careful historical account of the close social and political ties between the French magistracy and political elites, magistrates being described as always in tension between social deference towards the bearers of political power (in their capacity to support the professional careers of magistrates) and the willingness to escape the most compromising practices that may be entailed (Bancaud, I989). The magistracy was thus characterised by its regular obedience to the state, notably in critical times such as World War II (Bancaud, 2002). The sociohistorical dimension that one can observe in his analysis was a major dimension also nurtured by Anne Boigeol, who developed a totally new trend in French socio-legal research by addressing the issue of gender, by working on the feminisation of the legal professions in France. As in other social domains, she shed light on a glass ceiling, from the bench of the magistrates' school (Boigeol, I996) to the election of the first woman to the head of the Parisian bar (Boigeol, 2007).

If Bancaud or Boigeol were keen to address the socio-historical evolution of the legal professions in term of relations of power and a logic of interests, if Dezalay, with Bryant Garth, depicted lawyers as 'merchants of law', Lucien Karpik dramatically challenged this analysis in his history of the legal professions. His masterpiece on lawyers was translated almost immediately into English (Karpik, I999) and entailed a totally different point of view on the growth of the profession. Karpik identified politics as defining the identity of the lawyers. Advocates, in tension between the state, 
the market and the public, developed a strong commitment to the advocacy of the public interest, notably between the French Revolution and World War II. The stress was then, in Karpik's analysis, on two major points: first, the insistence on the economic disinterest of the profession as a whole, and second, on its commitment towards political liberalism. Lawyers, in Karpik's analysis, are historically committed to liberal politics, even despite their private interests. Nevertheless, the economics of the professions, far from being neglected, are at the core of the study of the contemporary legal profession, described in terms of 'economics of quality'. Karpik thus addresses a critique to the law and economics paradigm and its market-oriented analysis, to focus on the asymmetrical knowledge at stake when a client is looking for the best legal advice.

The focus on economic interest, already discussed by Anne Boigeol in the early I980s (Boigeol, I98I), was central in the definition of the political role of lawyers, or of the legal professional more generally: were they playing politics in fostering their private interests, even at the price of internal divisions (Dezalay, I990), or should they be considered as political actors whose actions were subsumed by the general interest? This issue became all the more important as a topic, and more precisely two words, 'judicialisation' (judiciarisation) and 'juridicisation' (juridicisation), entered the field and gained in interest for social scientists. As Jacques Commaille and Laurence Dumoulin recalled it in a recent article, the trend towards the focus on the growing impact of law on politics was shared among industrial countries in the I99os (Commaille and Dumoulin, 2009). In France, a collection of papers emanating from a workshop and published under the title $\mathrm{La}$ juridicisation du politiques. Leçons politiques [The Juridicisation of Politics. Political Lessons] (Commaille, Dumoulin and Robert, 2000) was the first step towards the recognition and the dissemination of the concept. The idea was to emphasise the need to take into account the political dimension of law, challenging both the traditional defence of law as neutral on the part of jurists, and the lack of interest towards legal subjects then widespread among political scientists. The emphasis on law and politics met with considerable success, notably because the period was more generally characterised, on the political stage, by judicial assertiveness in the investigation and prosecution of political activities. As Violaine Roussel brilliantly showed (Roussel, 2002), the relationships between judges and politicians changed in the I990s, as evidenced by a number of political scandals. The judicial world gained in autonomy, by comparison with the period analysed by Alain Bancaud, and strongly challenged the tacit judicial impunity that politicians had traditionally enjoyed in contemporary France. It is also interesting to remark that similar trends have been identified in Italy, in particular by Antoine Vauchez (Vauchez, 2004), who also stressed the impact of the unionisation of magistrates developed in Italy and France in the last quarter of the twentieth century. Being more visible, the judicialisation of politics was not, however, unquestionable. Indeed, in a later paper (Roussel, 2003), Roussel also stressed the fact, that the term judiciarisation itself in French was first and foremost used by political actors, for example by former Prime Minister Alain Juppé, who was targeted by judges for having provided, while in office at Paris City hall, a low rent public housing apartment in a very chic neighbourhood for his son. In Juppés words, the judicialisation of politics was of course something bad and to be avoided. Were judicialisation and juridicisation, in addition to being unpronounceable, pre-notions in the Durkheimian sense of the term? This would mean that sociologists should avoid their use, the risk being to consider as evident a process that is not scientifically documented. But one can also consider that a careful definition of those terms is useful. Far from being synonymous, as Jérôme Pélisse showed, those processes must be distinguished one from the other. Indeed, in the private companies he observed, more juridicisation - to be understood as a growing presence of rules - can be associated with de-judicialisation (that is less litigation). In those cases, legislative complexity serves as an obstacle to legal mobilisation in the absence of collective action (Pélisse, 2009).

If the interrelation of law and politics is at the core of the debate concerning contemporary France, it has also been revisited to open up new perspectives in the sociohistorical approach to 
analyses of the French past. The lens of legal categories was useful for investigating the colonial empire, to discover how the colonising power framed the colonial experience to legitimise the conquest and the colonisation, as well as to administer the subjugated populations. The legality of the colonial empire was a powerful site to demonstrate the frailty of the Republican model of citizenship, as previously described by historians (Rosanvallon, I992). Laure Blévis demonstrated for Algeria (Blévis, 200I), and Emmanuelle Saada showed in her study of infants of mixed parentage in Indochina (Saada, 2007), how hidden racial categories interfered with the Republican ones. More generally, the Third Republic, often described as 'la République des Avocats' ['Lawyers' Republic'], has been carefully studied by paying attention to social trajectories, to reconsider the legend the lawyers themselves had built (Willemez, I999). The use of archival work to deeply renew knowledge of the past in its legal dimensions was also useful for analysing resistance among lawyers during World War II. The hidden transcripts (Scott, I990) of their practice were reconstructed to deepen the analysis of legal mobilisation in non-democratic contexts, and to shed light on the peculiar legitimacy of the legal framing in such a conflict (Israël, 2005). Law can be considered as a weapon in various contexts (Israël, 2009), including France, and both legal mobilisation analysis (McCann, 2006) and the cause lawyering framework (Gaïti and Israël, 2003) are useful in articulating law and collective action in various situations, paying attention to the role of lawyers in the building of a cause. A traditional non-governmental organisation, the 'Ligue des Droits de l'Homme' ['Human Rights League'] was also reconsidered by paying attention to its careful use of law, between politics and humanitarian action, in colonial Algeria and in France (Blévis, 2003; Agrikoliansky, 2003). In various contexts, the role of lawyers (either attorneys, state officials or members of private organisations) was revealed to stress their contribution to the political domain, beyond the classical 'political lawyer' model.7

If law was to be regarded as highly political, it was indeed also in the ways the state and other institutional actors made use of it. The junction between the sociological analysis of public action and the interest towards law profoundly renewed the ancient conception, incarnated by Carbonnier, where sociology was applied knowledge used to inform legislation. The study of political reforms and their implementation has been a crucial locus to experiment the merging of the tools of political analysis and the resources of legal sociology (Duran, I999). Pierre Lascoumes's analysis of environmental policies well depicted how legal implementation, far from being unambiguous, was at the crossroads of plural local interests and was thus to be analysed as a co-production and a collective performance (Lascoumes, I995). The politics of the judicial map (Commaille, 2000), the reform of justice in France or other European countries (Vauchez and Willemez, 2007; Vigour, 2004; Delpeuch and Vassileva, 2007), the increasing use of new technologies in the administration of justice (Dumoulin and Licoppe, 20II; Kaluszynski, 2007), the regulation of religion, notably concerning the Islamic head scarf (Galembert, 2008), the development of gender policies in France and Québec (Revillard, 2009), or the policies designed to increase the proportion of minorities in private companies (Bereni, 2009) and prevent discrimination (Chappe, 20II) were the numerous sites for the renewal of the understanding of state policies. The renewed understanding of the functioning of the state in relation to its legal tools was also profoundly transformed by the rediscovery of Foucaldian analysis. Foucaldian thinking, which in the past may have been characterised by his neglect or even 'expulsion' of law (Hunt, I992), was profoundly reshaped by the publication of the lectures that Foucault gave at the Collège de France during his last years. With the concept of governmentality, Foucault opened the way to a new approach on how the state operates through laws, considered as its instrument of action (Lascoumes and Le Galès, 2005).

7 For the controversy on the question between Lucien Karpik, Terry Halliday and Rick Abel, see <http://jurist. law.pitt.edu/lawbooks/revapror.htm\#KarpikHalliday>. 
It is certainly not by chance that the state was more often studied by socio-legal scholars in France than in other countries. The role of the central state in France in political and administrative areas had already been discussed by Alexis de Tocqueville in his famous comparison with the US, and is obvious still today in comparison with other Western countries. Nevertheless, this role has been challenged, particularly in the last thirty years, notably by neoliberal policies, European integration and national decentralisation. Accordingly, most of those studies identified tensions between legal authorities, and particularly between courts and parliaments, but also between various public agencies. The studies of legal implementation mentioned contributed strongly to identifying a multilayered state, far from univocal in its relation to law. Those tensions can also be considered as resources, in particular for social movements which can move from one arena to another. More generally, the legal discourse, including or excluding legal mobilisation, opened the way to social movements in the name of law and its universality, even despite their lack of resources. Daniel Mouchard well identified how 'un-movements' [mouvements des sans-], undocumented persons, un-lodged or un-employed, for example, used the legal repertoire of action, including calling themselves by names referring to rights ('Droits devant!', 'Droit au Logement', etc.) (Mouchard, 2003). In this perspective, the courts were all the more open to political mobilisation than the state, which was trying to escape the debate, as, for example, with the Islamic headscarf in the Ig9os (Bowen, 2007; Galembert, 2008). As Richard Abel had already identified in an international comparative study of legal mobilisation, in some occasions 'speaking law to power' is a powerful strategy for social movements (Abel, I998). This may be especially true in the French context, where the bureaucratic state relies heavily on the legalistic framework so well depicted by Max Weber.

The study of the legal dimensions of public institutions in context was often associated with a bottom-up approach, leading some researchers to the street-level bureaucrats of French administration. Alexis Spire documented the margins of action available at the administrative office concerning immigrant rights (Spire, 2008), opening the field to other detailed analyses of the treatment of migrants, seen as a boundary of state legality (Fischer, 2013). The reach of law has thus been more precisely seized (Israël, Sacriste, Vauchez and Willemez 2005), even if numerous fields of research remain to be covered.

\section{Conclusion}

If law as a subject of interest for social sciences gained enormously in importance in France in the last few years, it is also clear that transnational and international influences are shaping developments within France. To be sure, the Law and Society Association, in conjunction with the growing success of the $\mathrm{RCSL}^{8}$, may be considered a major factor in the growing interest towards socio-legal studies in France. But, as a matter of fact, the development of transnational institutions, at the European level (Chiapello and Medjad, 2007; Guiraudon, 2009; Vauchez and Cohen 20II) and in international courts (Seroussi, 2006; Claverie, 2009), or more generally concerning conflict resolution (Lefranc, 2009), is at the same time sustaining a broad expansion of transnational legality as a legal phenomenon and an international subject of research, including French academics, among other scholars. That said, if something French may be relevant to observe in the current sociology of law, it could be this double trend towards an emancipation of the field from its legal background, and a legitimisation of legal subjects in the broader domain of social sciences. In this context, the growing inclusion of law and its realms of action in the French 'sociological reasoning', to quote Jean-Claude Passeron (Passeron, I99I) when he described an

8 The Research Committee on Sociology of Law (International Sociological Association). 
institutionally patterned definition of a discipline, is certainly important for French sociology as well as for our knowledge of law, since this development is based on diverse empirical studies.

Another interesting trend of socio-legal research in France may be the paradoxical absence of what is often called 'French Theory' in this body of work. Contrarily to English-speaking colleagues, notably from the US or the UK, some famous French authors, such as Baudrillard, Lyotard, Rancière or Nancy, are almost never cited. As Cusset explained it, French Theory is a melting pot of authors of French origin often barely read in France (Cusset, 2003). It is not true of Michel Foucault, Bruno Latour or Pierre Bourdieu, of course, but their use is rather different in French legal sociology than, for example, in critical legal scholarship, where they are part of post-modern theory. In contrast, in the French context, Foucault, Latour or Bourdieu have been, as we have seen, rediscovered as mentors in the redefinitions of the ever-moving and contextual relationship between law and society. The most interesting part of recent French sociology may not be then, as expected, theory, but the variety of methods and the diversity of results produced in fieldwork-oriented research. The orientation toward empirical studies may then contribute to sustaining the ability to overcome the so-called obstacle of the variety of national legal cultures, to share more easily methods and results among academics at the international level. If the divide between the civil-law and the common-law tradition is no longer an obstacle to a shared understanding of the relations between law and society in various settings, it may be time to reverse the question and to analyse empirically and comparatively the complex ways in which, at various levels including national and transnational ones, law and society are mutually constitutive. In this regard, the French approach has stressed, more than others, the role of the state. This emphasis may be of general interest, and reveal the growing complexity of the multilevel relations between the law and the state in a globalised world.

\section{References}

ABEL, Richard (1998) 'Speaking Law to Power: Occasions for Cause Lawyering', in Austin Sarat and Stuart Scheingold (eds), Cause Lawyering: Political Commitments and Professional Responsibilities. New York: Oxford University Press, 69-II 7.

ACKermann, Werner and BASTARD, Benoît (I990) 'La gestion du changement dans les tribunaux de grande instance : une étude organisationnelle', Droit et société I6: 303-20.

AGRIKOLIANSKY, Éric (2003) 'Usages choisis du droit. Le service juridique de la LDH entre politique et raison humanitaire', Sociétés contemporaines 52: 6I-84.

Andrini, Simona and ARnaud, André-Jean (1995) Jean Carbonnier, Renato Treves et la sociologie du droit. Archéologie d'une discipline (droit et société). Paris: LGDJ.

ARNAUd, André-Jean (ed.) (I993) Dictionnaire Encyclopédique de théorie et de sociologie du droit. Paris: LGDJ. ARnAud, André-Jean and noreau, Pierre (1998) 'The Sociology of Law in France: Trends and Paradigms', Journal of Law and Society 25(2): 000-000.

ASSIER-ANDRIEU, Louis (I996) Le droit dans les sociétés humaines (Collection Essais et recherches). Paris: Nathan.

BANCAUd, Alain (I989) 'Une constance mobile. La haute magistrature', Actes de la Recherche en Sciences Sociales 76(76/77): 30-48.

BANCAUD, Alain (2002) Une exception ordinaire: la magistrature en France 1930-1950. Paris: Gallimard, NRF Essais.

BASTARD, Benoît and mouHANNA, Christian (2007) Une justice dans l'urgence, Le traitement en temps réel des affaires pénales. Paris, PUF.

BERENI, Laure (2009) “'Faire de la diversité une richesse pour l'entreprise." La transformation d'une contrainte juridique en catégorie managériale', Raisons politiques 35: 87-106.

BLÉvis, Laure (200I) 'Les avatars de la citoyenneté en milieu colonial ou les paradoxes d'une catégorisation', Droit et Société 48: 557-8I. 
BLÉvIS, Laure (2003) 'De la cause du droit à la cause anticoloniale. Les interventions de la Ligue des Droits de l'Homme en faveur des “indigènes" algériens pendant l'entre-deux guerres', Politix 62: 39-64.

Boigeol, Anne (I98I) 'De l’idéologie du désintéressement chez les avocats', Sociologie du travail, I/8I: $78-85$.

Boigeol, Anne (I996) 'Les femmes et les Cours. La difficile mise en œuvre de l'égalité des sexes dans

l'accès à la magistrature', Genèses 22: 107-29.

Boigeol, Anne (2007) 'Le genre comme ressource dans l'accès des femmes au "gouvernement du barreau”: l'exemple du barreau de Paris', Genèses 67: 66-88.

Boltanski, Luc and тHÉvenot, Laurent (2006) On Justification: The Economies of Worth. Princeton, NJ: Princeton University Press.

Boltanski, Luc, Claverie, Elisabeth, OfFenstadt, Nicolas and van Damme, Stéphane (eds) (2007) Affaires, scandales et grandes causes: de Socrate à Pinochet. Paris: Stock.

Boudon, Raymond and Davidovitch, André (I964) 'Les mécanismes sociaux des abandons de poursuites, analyse expérimentale par simulation', L'année sociologique Troisième série: I I I-244. BOURDIEU, Pierre (I986) 'La force du droit. Pour une sociologie du champ juridique’, Actes de la Recherche en Sciences Sociales 64: 3-19 ['The Force of Law: Toward a Sociology of the Juridical Field', Hastings Journal of Law 38: 805-53, 1987].

BOURDIEU, Pierre (2012) Sur l'État. Cours au Collège de France. Paris: Raisons d'agir/Seuil.

Bowen, John (2007) Why the French Don't Like Headscarves: Islam, the State, and Public Space. Princeton, N): Princeton University Press.

CARbonnier, Jean (I969) Pour une sociologie du droit sans rigueur. Paris: LGDJ.

CASTEL, Robert (2003) L’insécurité sociale. Qu'est-ce qu'être protégé. Paris: Seuil/La République des idées. CHAPPE, Vincent-Arnaud (20I I) 'Le cadrage juridique, une ressource politique? La création de la Halde comme solution au problème de l'effectivité des normes anti-discrimination (I998-2005)', Politix 94: 107-30.

CHIAPELLo, Eve and medjAD, Karim (2007) 'Une privatisation de la norme inédite: le cas de la politique comptable européenne', Sociologie du Travail 49(I): 46-64.

CHristin, Angèle (2008) Comparutions immédiates. Enquête sur une pratique judiciaire (coll. textes à l'appui/enquêtes de terrain). Paris: La Découverte.

CLAVERIE, Elisabeth (2009) 'La Violence, le procès, et la Justification, Scènes d'audience au TPIY', in Marc Breviglieri, Claudette Lafaye and Danny Trom (eds), Compétences critiques et sens de la justice. Paris: Economica, I07-23.

COCHOY, Franck, GAREL, Jean-Pierre and DE TERSAC, Gilbert (I998) 'Comment l'écrit travaille l'organisation: le cas des normes ISO 9000', Revue française de sociologie 39: 673-99.

Collin, Francis, DHoquois, Régine, goutierre, Pierre-Hubert, JeAmmaud, Antoine ... [etc.] (I980) Le droit capitaliste du travail (Collection Critique du droit). Grenoble: Presses Universitaire de Grenoble.

commaille, Jacques (I99I) ‘Normes juridiques et régulation sociale. Retour à la sociologie générale', in Jacques Commaille and François Chazel, Normes juridiques et régulation sociale (Collection droit et société). Paris: LGDJ, I3-24.

commaille, Jacques (2000) Territoires de justice. Une sociologie politique de la carte judiciaire (coll. Droit et Justice). Paris: PUF.

commaille, Jacques (2007) 'La construction d'une sociologie spécialisée. Le savoir sociologique et la sociologie juridique de Jean Carbonnier', L'Année Sociologique 57(2): 275-99.

commaille, Jacques and dumoulin, Laurence (2009) 'Heurs et malheurs de la légalité dans les sociétés contemporaines. Une sociologie politique de la "judiciarisation", L’Année sociologique 59: 63-107.

COMmaille, Jacques, Dumoulin, Laurence and ROBERT, Cécile (eds) (2000) La juridicisation du politique. Leçons scientifiques (Collection droit et société [new edition, 20Io, coll. Classics]). Paris: LGDJ. 
commaille, Jacques and duran, Patrice (2009) 'Pour une sociologie politique du droit: Présentation', L’Année sociologique 59: I I-28.

COtTereau, Alain (2002) 'Droit et bon droit. Un droit des ouvriers instauré, puis évincé par le droit du travail', Annales. Histoire, Sciences sociales 57(6): I 52 I-57.

cusset, François (2003) French Theory. Foucault, Derrida, Deleuze \& Cie et les mutations de la vie intellectuelle aux États Unis. Paris: La Découverte.

DELPEUCH, T. and VASSILEVA, M. (2007) 'Quelle portée des réformes judiciaires en Bulgarie? Comment les acteurs domestiques s'arrangent des prescriptions internationales', in Jacques Commaille and Martine Kaluszynski (eds), La fonction politique de la justice (Recherches/Territoires du politique). Paris, La Découverte, 69-93.

DELPLA, Isabelle (2012) Le mal en procès. Eichmann et les théodicées modernes (Collection L'avocat du diable). Paris: Hermann.

DeZalay, Yves (I990) 'Juristes purs et marchands de droit. Division du travail de domination symbolique et aggiornamento dans le champ du droit', Politix 3(IO-II): 70-9I.

Dezalay, Yves, sarat, Austin and silbey, Susan S. (I989) 'D’une demarche contestaire a un savoir meritocratique', Actes De La Recherches En Sciences Sociales 78: 79-93.

DIDRY, Claude and TESSIER, Luc (I996) 'La cause de l'emploi. Les usages du droit dans la contestation de plans sociaux', Travail et emploi 69: 23-36.

Dumoulin, Laurence and LicopPe, Christian (20I I) 'La visioconférence dans la justice pénale: retour sur la fabrique d'une politique publique', Les cahiers de la justice 2: 29-52.

DupRé Du boulois, Xavier and Kaluszynski, Martine (20I I) Le droit en révolution(s). Regards sur la critique du droit des années 1970 à nos jours (Collection Droit et Société). Paris: LGDJ.

DUPRET, Baudouin (2006a) Le jugement en action. Ethnométhodologie du droit, de la morale et de la justice en Egypte (Collection Travaux de sciences sociales). Genève: Droz.

DUPRET, Baudouin (2006b) Droit et sciences sociales (Collection Cursus sociologie). Paris: Armand Colin. Duran, Patrice (1999) Penser l'action publique. Paris: LGDJ.

FISCHER, Nicolas (2013, forthcoming) Le territoire de l'expulsion. La rétention administrative des étrangers et l'État de droit dans la France contemporaine (Collection Le Gouvernement en Questions). Lyon: Presses de l’École Normale Supérieure de Lyon.

fRAENKel, Béatrice, PONTILle, David, Collard, Damien and Deharo, Gaëlle (20I0) Le travail des huissiers. Transformations d'un métier de l'écrit. Toulouse: Octares Éditions.

GAїTI, Brigitte and ISRAËL, Liora (2003) 'Sur l'engagement du droit dans la construction des causes', Politix 62: 17-30.

Galanter, Marc (I974) 'Why the "Haves" Come Out Ahead: Speculations on the Limit of Legal Change', Law and Society Review 9(I): 95-I60.

GALEMBERT, Claire de (2008) 'Le voile en procès', Droit et Société 66: I I-3I.

GARCIA-VILLEGas, Mauricio (2009) 'Champ juridique et sciences sociales en France et aux Etats-Unis', L'Année sociologique 59(I): 29-62.

Ginzburg, Carlo (I980) The Cheese and the Worms: The Cosmos of a Sixteenth Century Miller. Baltimore, MD: Johns Hopkins University Press [first published in Italian as Il formaggio e I vermi, I976]. GUIRAUdon, Virginie (2009) 'Equality in the Making: Implementing European non-Discrimination Law', Citizenship Studies I3(5): 527-48.

HERPIN, Nicolas (1973) Les sociologues américains et le siècle. Paris: Seuil.

HERPIN, Nicolas (1977) L'application de la loi. Deux poids deux mesures. Paris: Seuil.

HERPIN, Nicolas (I98I) 'Le dossier pénal et son double', Sociologie du travail I: 44-49.

HERPIN, Nicolas (200I) Sociologie de la consommation (Collection Repères). Paris: La Découverte.

Heurtin, Jean-Philippe and molfessis, Nicolas (eds) (2006) La sociologie du droit de Max Weber. Paris: Dalloz.

Hunt, Alan (I992) 'Foucault Expulsion of Law: Toward a Retrieval', Law and Social Inquiry I7(I): I-38. 
ISRAËL, Liora (2005) Robes noires, années sombres. Avocats et magistrats en résistance pendant la Seconde Guerre mondiale (Collection Pour une histoire du XXème siècle). Paris: Fayard.

ISRAËL, Liora (2009) L'arme du droit (Collection Contester). Paris: Presses de Sciences Po.

ISRAËL, Liora, SACRISTE, Guillaume, VAUCHEZ, Antoine and WILlEMEZ, Laurent (2005) Sur la portée sociale du droit. Usages et légitimité du registre juridique (Collection CURAPP). Paris: PUF.

KALUSZYNSKI, Martine (2007) 'Le développement du placement sous surveillance électronique en

Europe: Genèses, circulation des modèles et diversité des problématiques', in JeanCharlesFroment and MartineKaluszynski, Justice et technologies. Surveillance électronique en Europe. Grenoble: PUG, I3-28.

KARPIK, Lucien (I999) French Lawyers. A Study in Collective Action, I274 to I994. Oxford: Oxford University Press.

LASCOUMES, Pierre (I995) 'Les arbitrages publics des intérêts légitimes en matière d'environnement', Revue Française de Science Politique 45(3): 396-4I9.

LASCOUmes, Pierre and le Galès, Patrick (2005) Gouverner par les instruments (Académique). Paris, Presses de Sciences Po.

LASCOUmes, Pierre and SERverin, Evelyne (I988) 'Le droit comme activité sociale. Pour une approche weberienne des activités juridiques', Droit et Société 9: I7 I-93.

Latour, Bruno (2002) La Fabrique du droit. Une ethnographie du Conseil d'État (La Découverte Poche/ Sciences humaines et sociales I9I). Paris, La Découverte.

LATour, Bruno (2005) Reassembling the Social: An Introduction to Actor-Network Theory. Oxford: Oxford University Press.

Latour, Bruno and woolgar, Steve (I979) Laboratory Life: The Construction of Scientific Facts. Beverly Hills, CA: Sage Publications.

Latour, Bruno (20I0) The Making of Law. An Ethnography of the Conseil d'État. Cambridge: Polity Press. LEFRANC, Sandrine (2009) 'La professionnalisation d'un militantisme réformateur du droit: l'invention de la justice transitionnelle', Droit et Société 73: 56I-89.

LEMERCIER, Claire (2008) 'Discipliner le commerce sans corporations. La loi, le juge, l'arbitre et le commerçant', Le Mouvement social 224(3): 6I-74.

LENoIr, Rémi (2003) Généalogie de la morale familiale. Paris: Seuil.

MCCAnn, Michael (I994) Rights at Work. Pay Equity Reform and the Politics of Legal Mobilization. Chicago,

IL: University of Chicago Press.

mCCAnN, Michael (ed.) (2006) Law and Social Movements. Aldershot: Ashgate.

mouchard, Daniel (2003) 'Une ressource ambivalente: les usages du répertoire juridique par les mouvements des "sans", Mouvements 29: 55-59.

MOURALIS, Guillaume (2008) Une épuration allemande: la RDA en procès. Paris: Fayard.

oCQueteau, Frédéric and soubiRAn-PAILlet, Francine (I996) ‘Champ juridique, juristes et règles de droit: une sociologie entre disqualification et paradoxes', Droit et Société 32: 9-26.

ogien, Albert (1999) 'Situation de décision: une analyse des pratiques d'attribution d'argent public', Droit et Société 42/43: 365-92.

PASSERON, Jean-Claude (I99I) Le raisonnement sociologique. L'espace non-popperien du raisonnement naturel. Paris: Nathan.

PÉLISSE, Jérôme (2003) ‘Conscience du temps et conscience du droit chez des salariés à “35h”, Droit et Société 53: I63-86.

PÉLISSE, Jérôme (2005) 'A-t-on conscience du droit? Autour des Legal Consciousness Studies', Genèses 59: II $4-30$.

PÉLISSE, Jérôme (2009) 'Judiciarisation ou juridicisation? Usages et réappropriations du droit dans les conflits du travail', Politix 86(2): 73-96.

PINTO, Louis (I989) 'Du “pépin” au litige de consommation', Actes de la Recherche en Sciences Sociales 76 (76/77): 65-8I. 
PINTo, Louis (2007) La Vocation et le métier de philosophe. Pour une sociologie de la philosophie dans la France contemporaine. Paris: Le Seuil.

POUlANTZAS, Nicolas (I965) Nature des choses et droit, essai sur la dialectique du fait et de la valeur. Paris, LGDJ.

REVILLARD, Anne (2009) 'Quelle politique pour les femmes? Une comparaison France-Québec', Revue internationale de politique comparée I5(4): 687-704.

ROSANVALLON, Pierre (1992) Le sacre du citoyen. Histoire intellectuel du suffrage universel en France. Paris: Gallimard.

Roussel, Violaine (2002) Affaires de juges. Les magistrats dans les scandales politiques en France (I9902000). Paris: La Découverte.

Roussel, Violaine (2003) 'La judiciarisation du politique, réalités et faux semblants’, Mouvements 29(4): I3-I8.

Roussel, Violaine (2004) 'Le droit et ses formes. Éléments de discussion de la sociologie du droit de Pierre Bourdieu', Droit et Société; 56/57: 4I-55.

SAADA, Emmanuelle (2007) Les enfants de la colonie. Les métis de l'Empire français entre sujétion et citoyenneté. Paris: La Découverte.

Sarat, Austin and silbey, Susan S. (I988) 'The Pull of the Policy Audience', Law \& Policy Io(2/3): 97-I66. sAyn, Isabelle (2005) 'Jeux de rôle dans l'élaboration et la mise en œuvre du droit', in Liora Israël, Guillaume Sacriste, Antoine Vauchez and Laurent Willemez (eds), Sur la portée sociale du droit. Usages et légitimité du registre juridique (Collection CURAPP). Paris: PUF, I I I-26.

scotT, James (I990) Domination and the Arts of Resistance: Hidden Transcripts. New Haven, CT: Yale University Press.

SEROUSSI, Julien (2006) 'L'internationalisation de la justice transitionnelle: l'affaire Hissène Habré,

Critique internationale I(30): 83-IOI.

SERVERIn, Évelyne (2000) Sociologie du droit (Collection Repères). Paris: La Découverte.

SOUBIRAN-PAILLET, Francine (2000) 'Juristes et sociologues français d'après-guerre: une rencontre sans lendemain', Genèses 4I: I25-42.

SPIRE, Alexis (2008) Accueillir ou reconduire. Enquête sur les guichets de l'immigration. Paris: Raisons d'agir. stone sweEt, Alec (1992) The Birth of Judicial Politics in France: The Constitutional Council in Comparative

Perspective. New York: Oxford University Press.

THÉNAULt, Sylvie (200I) Une drôle de justice. Les magistrats dans la guerre d'Algérie. Paris: La Découverte. THÉRY, Irène (I993) Le démariage. Paris: Odile Jacob.

THÉRY, Irène (2010) Des humains comme les autres. Bioéthique, anonymat et genre de don. Paris: Éditions de l'EHESS.

THÉvENOT, Laurent (2006) 'L’action à bon droit: jugements ordinaires et jugements de droit', in L'action au pluriel. Sociologie des régimes d'engagement. Paris: La Découverte, I57-8I.

THIREAU, Isabelle and HUA, Linshan (200I) 'Le sens du juste en Chine: En quête d'un nouveau droit du travail', Annales, Histoire et Sciences Sociales 6: I283-3 г2.

TORNy, Didier (20I I) 'L'écriture administrative des circulaires, produit d'expertise technique ou norme juridique ?', in Christian Bessy, Thierry Delpeuch and Jérôme Pelisse (eds), Droit et régulations des activités économiques: perspectives sociologiques et institutionnalistes. Paris, LGDJ, 255-68.

vanneuville, Rachel (2009) 'Les enjeux politico-juridiques des discours sur l'inflation normative', Parlement(s) (Les juristes et la loi) i i: 80-9I.

vaUCHEz, Antoine (200I) 'Entre droit et sciences sociales: retour sur l'histoire du mouvement Law and Society', Genèses 45: 134-49.

vAUCHEZ, Antoine (2004) L'institution judiciaire remotivée. Le processus d'institutionnalisation d'une 'nouvelle justice' en Italie, 1960-2000 (Collection droit et société). Paris: LGDJ.

vaUCHEZ, Antoine (2005) 'Le droit en transitions. La Cinquième République naissante et l'invention d'un nouvel art législatif, in Liora Israël, Guillaume Sacriste, Antoine Vauchez and 
Laurent Willemez (eds), Sur la portée sociale du droit. Usages et légitimité du registre juridique (Collection CURAPP). Paris: PUF, 27I-89.

vAUCHEZ, Antoine and COHEN, Antonin (20I I) 'The Social Construction of Law: The European Court of Justice and Its Legal Revolution Revisited', Annual Review of Law and Society 7: 4I 7-3I. VAUCHEZ, Antoine and wILLEMEz, Laurent (2007) La justice face à ses réformateurs (1980-2006). Entreprises de modernisation et logiques de résistance. Paris: PUF. vigour, Cécile (2004) 'Réformer la justice en Europe. Analyse comparée des cas de la Belgique, de la France et de l'Italie', Droit et société I (56/57): 29I-323.

WELLER, Jean-Marc (2007) 'La disparition des bœufs du père Verdon. Travail administratif ordinaire et statut de la qualification', Droit et Société 67: 713-55.

WiLlEMEZ, Laurent (I999) 'La "République des avocats": le mythe, le modèle et son endossement', in Michel Offerlé (ed.), La profession politique (Collection Socio-histoire). Paris: Belin, 20I-29. 